\title{
Origin and transport of pore fluids in the Nankai accretionary prism inferred from chemical and isotopic compositions of pore water at cold seep sites off Kumano
}

\author{
Tomohiro Toki ${ }^{* *}$, Ryosaku Higa', Akira ljiri ${ }^{2}$, Urumu Tsunogai ${ }^{3,5}$ and Juichiro Ashi ${ }^{4}$
}

\begin{abstract}
We used push corers during manned submersible dives to obtain sediment samples of up to $30 \mathrm{~cm}$ from the subseafloor at the Oomine Ridge. The concentrations of B in pore water extracted from the sediment samples from cold seep sites were higher than could be explained by organic matter decomposition, suggesting that the seepage fluid at the site was influenced by B derived from smectite-illite alteration, which occurs between $50^{\circ} \mathrm{C}$ and $160^{\circ} \mathrm{C}$. Although the negative $\delta^{18} \mathrm{O}_{\mathrm{H} 2 \mathrm{O}}$ and $\delta \mathrm{D}_{\mathrm{H} 2 \mathrm{O}}$ values of the pore fluids cannot be explained by freshwater derived from clay mineral dehydration (CMD), we considered the contribution of pore fluids in the shallow sediments of the accretionary prism, which showed negative $\delta^{18} \mathrm{O}_{\mathrm{H} 2 \mathrm{O}}$ and $\delta \mathrm{D}_{\mathrm{H} 2 \mathrm{O}}$ values according to the results obtained during Integrated Ocean Drilling Program (IODP) Expeditions 315 and 316. We calculated the mixing ratios based on a four-end-member mixing model including freshwater derived from CMD, pore fluids in the shallow (SPF) accretionary prism sediment, seawater (SW), and freshwater derived from methane hydrate $(\mathrm{MH})$ dissociation. However, the Oomine seep fluids were unable to be explained without four end members, suggesting that deep-sourced fluids in the accretionary prism influenced the seeping fluids from this area. This finding presents the first evidence of deep-sourced fluids at cold seep sites in the Oomine Ridge, indicating that a megasplay fault is a potential pathway for the deep-sourced fluids.
\end{abstract}

Keywords: Cold seep; Pore fluid; Nankai Trough; Accretionary prism; Kumano; Boron; Lithium; Clay mineral dehydration; Methane hydrate dissociation

\section{Background}

At cold seeps, pore fluids seep from sea-bottom sediments. These seepage fluids are generally enriched in $\mathrm{CH}_{4}$ or $\mathrm{H}_{2} \mathrm{~S}$, and chemosynthetic communities such as bacterial mats and Calyptogena, which use $\mathrm{CH}_{4}$ or $\mathrm{H}_{2} \mathrm{~S}$ as an energy source, cluster on the seafloor at cold seep sites (Paull et al. 1984; Suess et al. 1985). Cold seep sites have been observed in subduction zones and in passive margins worldwide, and the seepage fluids have been reported to have various sources (Suess et al. 1985; Wallmann et al.

\footnotetext{
* Correspondence: toki@sci.u-ryukyu.ac.jp

${ }^{1}$ Department of Chemistry, Biology and Marine Science, Faculty of Science, University of the Ryukyus, 1 Senbaru, Nishihara, Okinawa 903-0213, Japan
} Full list of author information is available at the end of the article
1997; Aharon and Fu 2000; Lein et al. 2000; Naehr et al. 2000; Greinert et al. 2002). The Nankai Trough subduction zone is a convergent plate margin where the Philippine Sea plate is subducting below the Eurasian plate (Figure 1a). The surface sediments on the subducting plate have accreted on the landward slope of the Eurasian plate, forming an accretionary prism that consists of a toe, slope, and outer ridge. Within the slope sediments, megasplay faults branch from the plate-boundary interface and intersect the seafloor at the foot of the outer ridge (Park and Kodaira 2012; Park et al. 2002). One such intersection is the Oomine Ridge, where several bacterial mats have been observed on the seafloor (Toki et al. 2011, 2004).

$\mathrm{Cl}^{-}$concentrations in the pore fluids at the bacterial mats are lower than that in seawater (SW) (Toki et al. 


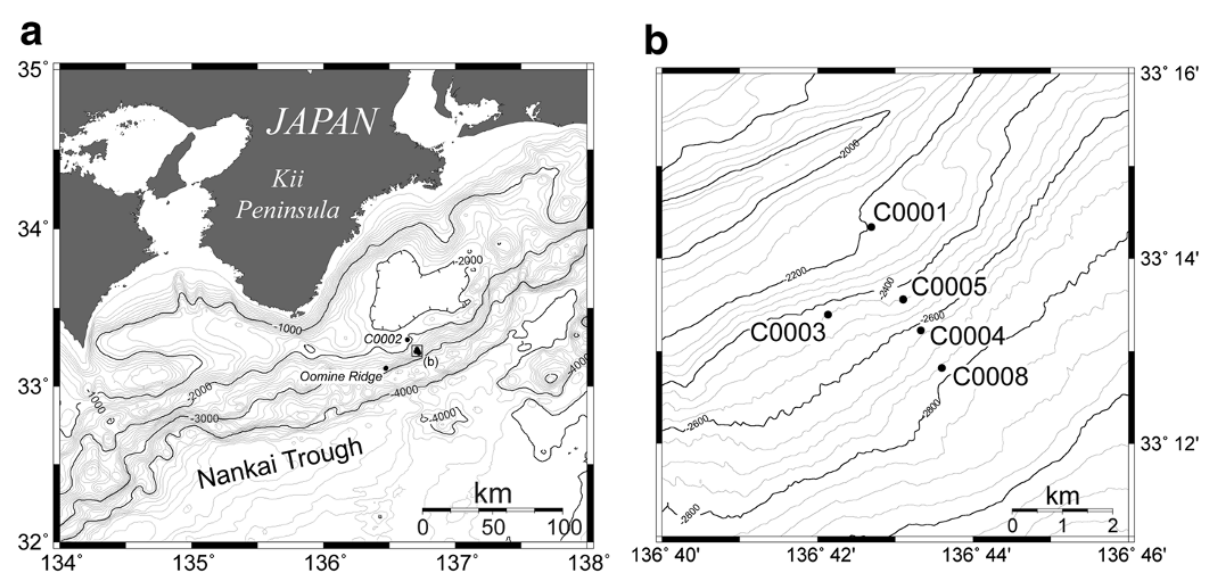

Figure 1 Bathymetric map and cross section of the Nankai Trough accretionary prism. (a) Bathymetric map of the Nankai Trough accretionary prism off Kumano showing the location of the Oomine Ridge together with the locations of Sites C0001, C0002, C0003, C0004, C0005, and C0008, drilled during Integrated Ocean Drilling Program (IODP) Expeditions 314, 315, and 316. Contour is $100 \mathrm{~m}$. A box indicates the area of Figure 1b. (b) Cross section of the Nankai Trough accretionary prism. Positions of drill Sites C0001, C0003, C0004, C0005, and C0008 are shown. Contour is $50 \mathrm{~m}$.

2004). Deviations of the chemical and isotopic compositions of the pore fluids from those of SW have been attributed to the mixing of fluids with compositions differing from those of SW (Kastner et al. 1991; Tsunogai et al. 2002; Dählmann and de Lange 2003; Mazurenko et al. 2003; Toki et al. 2004; Hiruta et al. 2009). Since each of these fluid sources is characterized by specific $\mathrm{O}$ and $\mathrm{H}$ isotopic compositions (e.g., Kastner et al. 1991). The seepage fluids on the Oomine Ridge have been inferred to originate from horizontally transported groundwater because the $\delta^{18} \mathrm{O}_{\mathrm{H} 2 \mathrm{O}}$ and $\delta \mathrm{D}_{\mathrm{H} 2 \mathrm{O}}$ values of the pore fluids at the cold seep sites on the Oomine Ridge are in the range of those of groundwater in coastal northwestern Japan (Toki et al. 2004).

In this study, we investigate the origin of the seepage fluids on the Oomine Ridge by examining concentrations of $\mathrm{B}$. The level of $\mathrm{B}$ in seepage fluids is controlled mainly by interactions of sediment or rock with water, which depends on the temperature of the reaction (You and Gieskes 2001). High B concentrations have been reported in pore fluids from mud volcanoes (Aloisi et al. 2004; Teichert et al. 2005; Haese et al. 2006; Hensen et al. 2007; Reitz et al. 2007; Chao et al. 2011). Proposed sources of high $\mathrm{B}$ concentrations in pore fluids are organic matter desorption at low temperature (Brumsack et al. 1992; You et al. 1993b) and smectite-illite alteration in the temperature range of $50^{\circ} \mathrm{C}$ and $160^{\circ} \mathrm{C}$ (You et al. 1996). The high temperatures required for such alteration occur at great depths in sediments and rocks of the Earth's crust, depending on the thermal gradient in a given area. Generally, average thermal gradients are between $50^{\circ} \mathrm{C} / \mathrm{km}$ and $60^{\circ} \mathrm{C} / \mathrm{km}$ (Parsons and Sclater 1977), and high-temperature environments of $150^{\circ} \mathrm{C}$ to $160^{\circ} \mathrm{C}$ are found at 2 to $3 \mathrm{~km}$ below the seafloor. Thus, by examining $\mathrm{B}$ concentrations, the contribution of deep-sourced fluids to pore fluids can be investigated (Martin et al. 1996; Aloisi et al. 2004; Haese et al. 2006). Using a submersible, we collected sediment samples from sediment depths of up to $30 \mathrm{~cm}$ at cold seep sites on the Oomine Ridge, and we evaluated the chemical and isotopic compositions, especially the B concentrations, of pore fluids extracted from the sediments. Then, we inferred the origins of the seepage fluids from these chemical and isotopic compositions.

\section{Methods}

\section{Sampling}

During cruise YK06-03 Leg 2 in May 2006 and cruise YK08-04 in April 2008 of the support ship Yokosuka of the Japan Agency for Marine-Earth Science and Technology (JAMSTEC), dive investigations were conducted by the JAMSTEC-manned submersible Shinkai6500 on the Oomine Ridge (Figure 1). Sampling point locations and descriptions of dive 949 (YK06-03 Leg 2) and dive 1062 (YK08-04) are shown in Table 1.

Sediment cores up to about $30 \mathrm{~cm}$ long were collected from cold seep sites on the Oomine Ridge with MBARItype push corers (http://www.mbari.org/dmo/tools/push_ cores.htm). After sediment recovery, the SW overlying the sediment in the corer was first drawn into a plastic syringe, and the filtered SW through a $0.45-\mu \mathrm{m}$ filter was then injected into a polypropylene bottle. These SW samples, obtained from a depth of $0 \mathrm{~cm}$ below the seafloor (bsf), were refrigerated at $4^{\circ} \mathrm{C}$ until analysis. After the overlying SW was removed from the corer, the sediment in the corer was subsampled at $5 \mathrm{~cm}$ intervals onboard using plastic syringes. Then, the pore water was extracted from the subsamples with a large clamp squeezer during 
Table 1 Location of sampling points during the YK06-03 nd YK08-04 cruises of the tender Yokosuka

\begin{tabular}{lllllll}
\hline Cruise & Date & Sample number & Latitude & Longitude & Depth $(\mathbf{m})$ & Description \\
\hline YK06-03 & 6 May 2006 & D949 C1 & $33^{\circ} 7.3283^{\prime} \mathrm{N}$ & $136^{\circ} 28.7705^{\prime} \mathrm{E}$ & 2,519 & Inside of a bacterial mat \\
& 6 May 2006 & D949 C3 & $33^{\circ} 7.2253^{\prime} \mathrm{N}$ & $136^{\circ} 28.6672^{\prime} \mathrm{E}$ & 2,533 & Inside of a different bacterial mat \\
YK08-04 & 6 April 2008 & D1062 C1 & $33^{\circ} 7.3481^{\prime} \mathrm{N}$ & $136^{\circ} 28.7341^{\prime} \mathrm{E}$ & 2,528 & Inside of a bacterial mat \\
& 6 April 2008 & D1062 C2 & $33^{\circ} 7.3481^{\prime} \mathrm{N}$ & $136^{\circ} 28.7301^{\prime} \mathrm{E}$ & 2,531 & Outside of a bacterial mat \\
& 6 April 2008 & D1062 C3 & $33^{\circ} 7.2348^{\prime} \mathrm{N}$ & $136^{\circ} 28.5974^{\prime} \mathrm{E}$ & 2,530 & Inside of a different bacterial mat \\
& 6 April 2008 & D1062 C4 & $33^{\circ} 7.2348^{\prime} \mathrm{N}$ & $136^{\circ} 28.5974^{\prime} \mathrm{E}$ & 2,530 & Outside of a different bacterial mat \\
& 6 April 2008 & D1062 C5 & $33^{\circ} 7.2348^{\prime} \mathrm{N}$ & $136^{\circ} 28.5974^{\prime} \mathrm{E}$ & 2,530 & Inside of the bacterial mat samples in D1062 C3 \\
\hline
\end{tabular}

cruise YK06-03 Leg 2 (Manheim 1968) and by centrifugation during cruise YK08-04 (Bufflap and Allen 1995).

\section{Analytical methods}

Subsamples of pore fluid and SW to be used for analysis of the concentrations and carbon isotopic compositions of dissolved $\mathrm{CH}_{4}, \mathrm{C}_{2} \mathrm{H}_{6}$, and total carbon dioxide $\left(\Sigma \mathrm{CO}_{2}=\right.$ $\mathrm{H}_{2} \mathrm{CO}_{3}+\mathrm{HCO}_{3}{ }^{-}+\mathrm{CO}_{3}{ }^{2-}$ ) were transferred to $2 \mathrm{~cm}^{3}$ glass vials containing $\mathrm{H}_{3} \mathrm{NSO}_{3}$ to convert the total dissolved carbonate to $\mathrm{CO}_{2}$ gas and $\mathrm{HgCl}_{2}$ to stop microbial activity. Subsamples of pore fluid and SW to be used for analysis of dissolved chemical components other than the aforementioned dissolved gases were transferred into $4 \mathrm{~cm}^{3}$ polypropylene bottles. The fluid samples in the polypropylene bottles were measured for $\mathrm{NH}_{4}\left(=\left[\mathrm{NH}_{4}{ }^{+}\right]+\left[\mathrm{NH}_{3}\right]\right)$ and $\mathrm{Si}\left(=\left[\mathrm{H}_{4} \mathrm{SiO}_{4}\right]+\left[\mathrm{H}_{3} \mathrm{SiO}_{4}{ }^{-}\right]\right)$concentrations in the shipboard laboratory onboard the tender (Gieskes et al. 1991).

After the fluid samples were transported to the laboratory on land, $\mathrm{Cl}^{-}$concentrations were measured by Mohr titration, and $\mathrm{SO}_{4}{ }^{2-}$ concentrations were measured by ion chromatography (Tsunogai and Wakita 1995). The K concentrations in the fluid samples were analyzed by Zeeman-type atomic adsorption spectrometry, and concentrations of the other major and minor elements, $\mathrm{Na}$, $\mathrm{Mg}, \mathrm{Ca}, \mathrm{B}\left(=\left[\mathrm{B}(\mathrm{OH})_{3}\right]+\left[\mathrm{B}(\mathrm{OH})_{4}{ }^{-}\right]\right), \mathrm{Sr}, \mathrm{Li}$, and $\mathrm{Ba}$, were analyzed by inductively coupled plasma-atomic emission spectrometry (ICP-AES) (Murray et al. 2000). The concentrations and carbon isotopic compositions of $\mathrm{CH}_{4}$, $\mathrm{C}_{2} \mathrm{H}_{6}$, and $\Sigma \mathrm{CO}_{2}$ in the samples for dissolved gas analysis (in the $2 \mathrm{~cm}^{3}$ vials) were measured by isotopic ratio mass spectrometry (Tsunogai et al. 2002; Miyajima et al. 1995). The analytical precision of each measurement technique is given in Table 2. In these measurements on land, the weights of the samples for all analyses were measured, and the concentrations are represented in units per kilogram.

The $\mathrm{O}$ isotopic composition of the water of the fluid samples was analyzed using an equilibration method with $\mathrm{NaHCO}_{3}$ as the reagent (Ijiri et al. 2003), and the $\mathrm{H}$ isotopic composition was analyzed by the $\mathrm{Cr}$ reduction method (Itai and Kusakabe 2004). The isotopic compositions are represented by $\delta$ notation relative to standard materials: Vienna Pee Dee Belemnite (VPDB) for carbon isotopes and Vienna Standard Mean Ocean Water (VSMOW) for $\mathrm{O}$ and $\mathrm{H}$ isotopes.

$$
\begin{aligned}
& \delta^{13} \mathrm{C}_{\text {carbon }}=\left(\left({ }^{13} \mathrm{C}_{\text {carbon }} /{ }^{12} \mathrm{C}_{\text {carbon }}\right)_{\text {sample }}\right. \\
& \text { / } \left.\left.\left({ }^{13} \mathrm{C}_{\text {carbon }} /{ }^{12} \mathrm{C}_{\text {carbon }}\right)_{\mathrm{VPDB}}\right)-1 \text { (\% VPDB }\right) \\
& \text { Carbon : } \mathrm{CH}_{4}, \mathrm{C}_{2} \mathrm{H}_{6}, \Sigma \mathrm{CO}_{2} \\
& \delta^{18} \mathrm{O}=\left(\left({ }^{18} \mathrm{O} /{ }^{16} \mathrm{O}\right)_{\text {sample }} /\left({ }^{18} \mathrm{O} /{ }^{16} \mathrm{O}\right)_{\text {vsmow }}\right) \\
& -1 \text { (\% VSMOW) } \\
& \delta \mathrm{D}=\left((\mathrm{D} / \mathrm{H})_{\text {sample }} /(\mathrm{D} / \mathrm{H})_{\text {VSMOW }}\right)-1(\% \text { VSMOW })
\end{aligned}
$$

\begin{tabular}{|c|c|c|}
\hline Component & Analytical method & Analytical error \\
\hline $\mathrm{pH}\left(25^{\circ} \mathrm{C}, 1 \mathrm{~atm}\right)$ & Potentiometry & $0.2 \%$ \\
\hline Alkalinity & Potentiometric titration & $1.2 \%$ \\
\hline $\mathrm{NH}_{4}^{+}$ & Colorimetry & $7.5 \%$ \\
\hline Si & Colorimetry & $1 \%$ \\
\hline $\mathrm{Cl}^{-}$ & Titration & $1 \%$ \\
\hline $\mathrm{SO}_{4}{ }^{2-}$ & Ion chromatography & $4 \%$ \\
\hline K & Atomic absorption spectrometry & $3 \%$ \\
\hline $\mathrm{Na}$ & ICP-AES & $7 \%$ \\
\hline $\mathrm{Ca}$ & ICP-AES & $4 \%$ \\
\hline $\mathrm{Mg}$ & ICP-AES & $1.2 \%$ \\
\hline B & ICP-AES & $3 \%$ \\
\hline Sr & ICP-AES & $3.5 \%$ \\
\hline Li & ICP-AES & $6 \%$ \\
\hline $\mathrm{Ba}$ & ICP-AES & $10 \%$ \\
\hline$\delta^{13} \mathrm{C}_{\mathrm{CH} 4}$ & Mass spectrometry & $0.3 \%$ \\
\hline$\delta^{13} \mathrm{C}_{\mathrm{C} 2 \mathrm{H} 6}$ & Mass spectrometry & $0.3 \%$ \\
\hline$\delta^{13} C_{\Sigma \mathrm{CO} 2}$ & Mass spectrometry & $0.3 \%$ \\
\hline$\delta^{18} \mathrm{O}_{\mathrm{H} 2 \mathrm{O}}$ & Mass spectrometry & $0.1 \%$ \\
\hline$\delta D_{\mathrm{H} 2 \mathrm{O}}$ & Mass spectrometry & $1 \% 0$ \\
\hline
\end{tabular}

Table 2 Analytical methods and errors for the measurement of chemical components in the pore water

ICP-AES, inductivity coupled plasma-atomic emission spectrometry. 


\section{Results}

$\mathrm{Cl}^{-}, \mathrm{Na}, \mathrm{Mg}, \mathrm{SO}_{4}{ }^{2-}, \mathrm{K}, \mathrm{Ca}, \mathrm{B}, \mathrm{Si}, \mathrm{Sr}, \mathrm{Li}, \mathrm{NH}_{4}{ }^{+}$, and $\mathrm{Ba}$ concentrations in the fluid samples collected during cruises YK06-03 (Leg 2) and YK08-04 are listed in Table 3, together with the concentration ratios of dissolved $\mathrm{CH}_{4}$ and $\mathrm{C}_{2} \mathrm{H}_{6}\left(\mathrm{CH}_{4} / \mathrm{C}_{2} \mathrm{H}_{6}\right)$, the $\mathrm{C}$ isotopic compositions of dissolved $\mathrm{CH}_{4}, \mathrm{C}_{2} \mathrm{H}_{6}$, and $\Sigma \mathrm{CO}_{2}\left(\delta^{13} \mathrm{C}_{\mathrm{CH} 4}\right.$, $\delta^{13} \mathrm{C}_{\mathrm{C} 2 \mathrm{H} 6}$, and $\delta^{13} \mathrm{C}_{\Sigma \mathrm{CO} 2}$ ) and the $\mathrm{O}$ and $\mathrm{H}$ isotopic compositions of the water $\left(\delta^{18} \mathrm{O}_{\mathrm{H} 2 \mathrm{O}}\right.$ and $\left.\delta \mathrm{D}_{\mathrm{H} 2 \mathrm{O}}\right)$. Vertical profiles of the concentrations of $\mathrm{Cl}^{-}, \mathrm{SO}_{4}{ }^{2-}, \mathrm{B}, \mathrm{Li}$, and $\mathrm{NH}_{4}{ }^{+}$and the isotopic information in the pore fluids are shown in Figure 2, since they are a focus of this paper. In this paper, we refer to sampling points inside the bacterial mats and tube worm colonies as 'cold seep sites' and those outside the bacterial mats as 'reference sites'.

The chemical and isotopic compositions of the fluid samples at cold seep sites differed from those at the reference sites (Figure 2). Regarding the curvatures in the graphs for $\mathrm{Cl}^{-}$and $\mathrm{SO}_{4}{ }^{2-}$, the upward curvatures appear to imply upward movement of waters from depth. The occurrence of bacterial mats suggests that some $\mathrm{CH}_{4}$ escapes to the surface to feed these mats (Gieskes et al. 2005). The curvatures of $\delta^{18} \mathrm{O}_{\mathrm{H} 2 \mathrm{O}}$ and $\delta \mathrm{D}_{\mathrm{H} 2 \mathrm{O}}$ are also apparent, especially in D949 C3, with some 'flyers' in the $\delta \mathrm{D}_{\mathrm{H} 2 \mathrm{O}}$ in the deeper part of $\mathrm{C} 3$. In a subsequent section, it is suggested that water flow does occur from greater depths. Therefore, this curvature must occur, with SW mixing occurring in the upper $10 \mathrm{~cm}$ of the cores.

The $\mathrm{Cl}^{-}$concentrations at the seafloor $($depth $=0 \mathrm{~cm}$ bsf) were averaged to be $547 \mathrm{mM}$ with a standard deviation of $8 \mathrm{mM}$ (Table 4). These samples correspond to bottom SW. The $\mathrm{Cl}^{-}$concentrations in these samples were almost consistent with that of North Pacific deep SW (548 mM; Reid 2009), suggesting the accuracy of the reported values. However, the standard deviation, at $1.5 \%$, is larger than the $1 \%$ analytical precision of the Mohr method (Table 1). This deviation is due not only to an influence of low- $\mathrm{Cl}^{-}$seep fluids because otherwise, the values would be lower than that of North Pacific deep SW. However, we also detected higher values than that of North Pacific deep SW (Table 3). The chemical characterization of $\mathrm{Cl}^{-}$is generally nonreactive, in which $\mathrm{Cl}^{-}$increases only by dissolution of evaporites. Evaporites rarely exist in natural environments and occur only around dry regions. Moreover, the existence of evaporites has not been reported near Nankai Trough. Unfortunately, we did not determine the reason for the higher values than that of North Pacific deep SW, although the lower $\mathrm{Cl}^{-}$concentration in the overlying SW at D949 C3 where the steepest curvature was observed in vertical profiles of chemical and isotopic compositions may be due to the influence of low- $\mathrm{Cl}^{-}$seep fluids (Figure 2).

\section{Discussion}

\section{Origin of B in of pore fluids at cold seep sites on the Oomine Ridge}

At cold seep sites on the Oomine Ridge, the B concentration in the pore fluids increased with depth (Figure 2). Possible sources of B are organic matter desorption, which occurs at relatively low temperatures (You et al. 1993b; Brumsack et al. 1992), and smectite-illite alteration, which occurs between $50^{\circ} \mathrm{C}$ and $160^{\circ} \mathrm{C}$ (You et al. 1996). Organic matter desorption is related to organic matter decomposition and thus results in well-correlated $\mathrm{B}$ and $\mathrm{NH}_{4}{ }^{+}$concentrations with $\Delta \mathrm{B} / \Delta \mathrm{NH}_{4}{ }^{+}$ratios of $0.1 \mathrm{~mol} / \mathrm{mol}$ (Teichert et al. 2005). In this study, $\Delta \mathrm{B} /$ $\Delta \mathrm{NH}_{4}{ }^{+}$was about $4 \mathrm{~mol} / \mathrm{mol}$ at the cold seep sites on the Oomine Ridge; thus, the ratio demonstrated $B$ enrichment by a factor of 40 compared with the expected ratio for organic matter desorption (Figure 3 ). This excess B suggests that B derived from smectite-illite alteration occurring in a higher-temperature environment is supplied to the pore fluids in the surface sediments at these cold seep sites and that the supplied fluids were subjected to temperatures between $50^{\circ} \mathrm{C}$ and $160^{\circ} \mathrm{C}$.

At Site C0001, near the surface trace of a megasplay fault in analogy with the Oomine Ridge, the coring was operated up to $458 \mathrm{~m}$ bsf during Integrated Ocean Drilling Program (IODP) Expedition 315 (Expedition 315 Scientists 2009a). The results indicated that the heat flow was $47 \mathrm{~mW} / \mathrm{m}^{2}$ and that there was no B enrichment. On the contrary, at Site C0002 on the northern rim of Kumano Basin (Expedition 315 Scientists 2009b), the maximum depth reached during the Expedition 315 drilling was $1,057 \mathrm{~m}$ bsf. In addition, the heat flow was $56 \mathrm{~mW} / \mathrm{m}^{2}$ (Harris et al. 2011) and there was no B enrichment. These heat flow data indicate that the hightemperature zone in which clay mineral dehydration (CMD) can occur was not reached by drilling in Kumano Basin. Thus, the lack of B enrichment at both sites implies that B-rich fluids at either depth did not pass through the hanging wall of the megasplay (C0001) or Kumano Basin (C0002). This result leads to the question of how B-rich fluids can flow to the Oomine Ridge.

In Nankai Trough off Muroto, high B concentrations in pore fluids up to $3 \mathrm{mmol} / \mathrm{kg}$ are shown in the décollement zone, which is attributed to fluid flow in the décollement zone (You et al. 1993a). In the Japan Trench forearc, B shows an increase in pore fluids, which is also attributed to fluid advection in sediments (Deyhle and Kopf 2002). In all cases, lower chlorides than that of SW were noted. Thus, inputs of B by fluid flow seem to be clear in these areas. In the Nankai forearc off Kumano, fluids may flow through the megasplay fault, although we were unable to detect corresponding B enrichment at Site C0004 penetrating the megasplay fault (Expedition 
Table 3 Chemical and isotopic compositions of pore water and bottoms SW

\begin{tabular}{|c|c|c|c|c|c|c|c|c|c|c|c|c|c|c|c|c|c|c|c|c|c|}
\hline Dive & Sample & Number & $\begin{array}{l}\text { Depth } \\
\text { cm bsf }\end{array}$ & $\begin{array}{l}\mathrm{Cl}^{-} \\
\mathrm{mmol} / \\
\mathrm{kg}\end{array}$ & $\begin{array}{l}\mathrm{Na} \\
\mathrm{mmol} / \\
\mathrm{kg}\end{array}$ & $\begin{array}{l}\mathrm{Mg} \\
\mathrm{mmol} / \\
\mathrm{kg}\end{array}$ & $\begin{array}{l}\mathrm{SO}_{4}{ }^{2-} \\
\mathrm{mmol} / \\
\mathrm{kg}\end{array}$ & $\begin{array}{l}\mathrm{K} \\
\mathrm{mmol} / \\
\mathrm{kg}\end{array}$ & $\begin{array}{l}\mathrm{Ca} \\
\mathrm{mmol} / \\
\mathrm{kg}\end{array}$ & $\begin{array}{l}\text { B } \\
\mu \mathrm{mol} / \\
\mathrm{kg}\end{array}$ & $\begin{array}{l}\mathrm{Si} \\
\mu \mathrm{mol} / \\
\mathrm{kg}\end{array}$ & $\begin{array}{l}\mathrm{Sr} \\
\mu \mathrm{mol} / \\
\mathrm{kg}\end{array}$ & $\begin{array}{l}\mathrm{Li} \\
\mu \mathrm{mol} / \\
\mathrm{kg}\end{array}$ & $\begin{array}{l}\mathrm{NH}_{4}^{+} \\
\mu \mathrm{mol} / \\
\mathrm{kg}\end{array}$ & $\begin{array}{l}\mathrm{Ba} \\
\mu \mathrm{mol} / \\
\mathrm{kg}\end{array}$ & $\begin{array}{l}\mathrm{CH}_{4} / \\
\mathrm{C}_{2} \mathrm{H}_{6}\end{array}$ & $\begin{array}{l}\delta^{13} \mathrm{C}_{\Sigma \mathrm{CO} 2} \\
\% \text { VPDB }\end{array}$ & $\begin{array}{l}\delta^{13} \mathrm{C}_{\mathrm{CH} 4} \\
\% \text { o } \\
\text { VPDB }\end{array}$ & $\begin{array}{l}\delta^{13} \mathrm{C}_{\mathrm{C2H6}} \\
\% \text { VPDB }\end{array}$ & $\begin{array}{l}\delta^{18} \mathrm{O}_{\mathrm{H} 2 \mathrm{O}} \\
\% \mathrm{o} \\
\text { VSMOW }\end{array}$ & $\begin{array}{l}\delta D_{\mathrm{H} 2 \mathrm{O}} \\
\% \text { o } \\
\text { VSMOW }\end{array}$ \\
\hline \multirow[t]{12}{*}{949} & $\mathrm{C} 1$ & 0 & 0 & 543 & 470 & 53.6 & 28.8 & 10.3 & 10.4 & 422 & 139 & 92.9 & 25.5 & 5 & & & & & & & \\
\hline & & 2 & 5 & 533 & 463 & 49.0 & 21.5 & 11.0 & 7.0 & 666 & 303 & 81.7 & 26.0 & 91 & & & -31.4 & -73.6 & & & \\
\hline & & 3 & 10 & 528 & 466 & 48.6 & 21.5 & 11.7 & 6.9 & 710 & 316 & 82.8 & 29.6 & 91 & & & -30.7 & -74.0 & & & \\
\hline & & 4 & 14 & & 474 & 50.6 & 23.6 & 11.7 & 8.0 & 655 & 287 & 85.8 & 27.5 & 68 & & & -29.4 & -78.5 & & & \\
\hline & & 5 & 19 & 541 & 462 & 48.8 & 32.2 & 11.4 & 7.3 & 659 & 270 & 84.2 & 29.0 & 75 & & & -28.6 & -77.4 & & & \\
\hline & & 6 & 23 & & 497 & 53.4 & 23.7 & 12.0 & 7.9 & 659 & 231 & 91.0 & 27.4 & 59 & & & -28.3 & -78.6 & & & \\
\hline & C3 & 0 & 0 & 534 & 481 & 54.2 & 28.1 & 10.7 & 10.6 & 438 & 164 & 95.0 & 26.2 & 11 & 0.3 & & & & & +0.16 & +1.1 \\
\hline & & 1 & 5 & 515 & 44 & 42.3 & 10.9 & 10.3 & 5.8 & 951 & 585 & 73.7 & 23.2 & 141 & 0.7 & 9,490 & -34.1 & -94.5 & -52.1 & -0.21 & -4.9 \\
\hline & & 2 & 10 & 505 & 436 & 39.1 & 4.6 & 9.7 & 2.9 & 1,193 & 431 & 67.4 & 23.2 & 153 & 1.1 & 12,300 & -36.4 & -93.3 & -47.5 & -0.40 & -3.5 \\
\hline & & 3 & 14 & 498 & 432 & 38.6 & 3.6 & 9.8 & 2.7 & 1,218 & 487 & 67.7 & 24.0 & 135 & 2.9 & 12,400 & -36.8 & -96.3 & -47.4 & -0.40 & -3.4 \\
\hline & & 4 & 19 & 503 & & & 4.4 & & & & 378 & & & 134 & 1.9 & 6,510 & -37.2 & -87.0 & -47.3 & +0.32 & -4.6 \\
\hline & & 5 & 23 & 496 & 452 & 39.2 & 3.0 & 10.1 & 2.8 & 1,283 & 349 & 67.5 & 24.8 & 137 & 1.4 & & & -88.2 & & -0.03 & -2.3 \\
\hline \multirow[t]{18}{*}{1062} & $\mathrm{C} 1$ & 0 & 0 & & & & & & & & & & & & & & & & & & \\
\hline & & 1 & 6 & 531 & 467 & 46.3 & 14.7 & 11.8 & 5.4 & 961 & & 73.7 & 28.1 & 188 & 2.3 & & -36.6 & -86.8 & & -0.29 & \\
\hline & & 2 & 11 & 517 & 451 & 42.5 & 7.1 & 11.7 & 3.4 & 1,171 & & 65.8 & 24.9 & 280 & 3.8 & & -36.6 & -86.8 & & -0.29 & \\
\hline & & 3 & 16 & 510 & 454 & 41.8 & 5.2 & 11.6 & 2.2 & 1,213 & & 60.7 & 23.9 & 294 & 5.5 & & -39.6 & -80.8 & & -0.30 & \\
\hline & & 4 & 21 & 517 & 441 & 40.8 & 3.2 & 11.2 & 1.0 & 1,242 & & 53.9 & 22.9 & 297 & 6.0 & & -35.4 & -92.4 & & -0.28 & \\
\hline & & 5 & 26 & 503 & 456 & 41.4 & 0.3 & 10.1 & 1.0 & 1,163 & & 54.1 & 23.0 & 294 & 18.8 & 4,040 & -38.9 & -86.4 & -41.5 & -0.40 & \\
\hline & $C 2$ & 0 & 0 & 551 & 472 & 52.4 & 27.5 & 10.0 & 403 & 403 & & 89.5 & 25.3 & 1 & & & & & & -0.32 & \\
\hline & & 1 & 3 & 545 & 473 & 51.7 & 28.3 & 10.6 & 10.1 & 424 & & 88.2 & 27.8 & 9 & & & -1.2 & -65.0 & & -0.30 & \\
\hline & & 3 & 13 & 540 & 472 & 51.6 & 27.1 & 10.8 & 9.9 & 430 & & 87.4 & 26.1 & 27 & & & -2.7 & -75.0 & & -0.21 & \\
\hline & & 4 & 18 & 534 & 473 & 51.4 & 27.2 & 11.1 & 9.8 & 428 & & 87.1 & 26.8 & 27 & & & -4.2 & -70.3 & & -0.36 & \\
\hline & & 5 & 23 & 538 & 471 & 51.3 & 27.6 & 10.9 & 9.8 & 437 & & 86.8 & 26.3 & 33 & & & -4.0 & -80.4 & & -0.32 & \\
\hline & C3 & 0 & 0 & 557 & 468 & 52.6 & 26.5 & 9.9 & 10.2 & 422 & & 91.8 & 26.1 & 17 & & & & & & +0.09 & \\
\hline & & 1 & 4 & 538 & 466 & 49.1 & 22.7 & 10.4 & 8.3 & 468 & & 88.1 & 26.4 & 164 & & & -26.6 & -82.0 & & -0.21 & \\
\hline & & 2 & 9 & 544 & 456 & 47.2 & 19.6 & 10.5 & 6.6 & 525 & & 83.0 & 27.2 & 144 & & & -32.2 & -82.2 & & -0.37 & \\
\hline & & 3 & 14 & & & & & & & & & & & & & & & & & & \\
\hline & & 4 & 19 & 531 & 456 & 45.6 & 16.0 & 10.5 & 5.6 & 637 & & 82.6 & 26.3 & 241 & & & -34.1 & -80.5 & & -0.35 & \\
\hline & C4 & 0 & 0 & 548 & 470 & 53.2 & 26.2 & 9.8 & 10.4 & 407 & & 91.5 & 26.3 & 2 & & & & & & -0.16 & \\
\hline & & 1 & 2 & 543 & 468 & 50.5 & 27.0 & 11.8 & 9.9 & 469 & & 89.4 & 28.8 & 10 & & & -6.6 & -58.4 & & -0.22 & \\
\hline
\end{tabular}


Table 3 Chemical and isotopic compositions of pore water and bottoms SW (Continued)

\begin{tabular}{|c|c|c|c|c|c|c|c|c|c|c|c|c|c|c|c|c|}
\hline & 2 & 7 & 538 & 470 & 50.4 & 26.6 & 11.7 & 9.8 & 499 & & 89.3 & 28.9 & 12 & -11.0 & -80.4 & -0.18 \\
\hline & 3 & 12 & 538 & 469 & 49.6 & 25.8 & 12.0 & 9.5 & 502 & & 88.8 & 23.8 & 22 & -15.7 & -81.7 & -0.18 \\
\hline & 4 & 17 & 536 & 466 & 48.7 & 23.7 & 11.3 & 9.2 & 510 & & 86.8 & 23.3 & 38 & -22.0 & -82.5 & -0.05 \\
\hline & 5 & 22 & 536 & 463 & 46.7 & 22.2 & 12.4 & 8.7 & 608 & & 84.4 & 27.1 & 56 & -25.0 & -82.2 & -0.04 \\
\hline \multirow[t]{6}{*}{ C5 } & 0 & 0 & 548 & 467 & 52.7 & 26.7 & 9.9 & 10.2 & 402 & & 913 & 23.8 & 3 & & & -0.20 \\
\hline & 1 & 4 & 536 & 460 & 46.0 & 46.0 & 19.7 & 12.7 & 8.7 & 668 & 86.2 & 28.3 & 97 & -29.8 & -73.0 & -0.33 \\
\hline & 2 & 9 & 532 & 491 & 45.2 & 18.2 & 12.4 & 6.3 & 721 & & 75.4 & 28.8 & 118 & -32.0 & -73.2 & -0.24 \\
\hline & 3 & 14 & 528 & 450 & 40.6 & 13.3 & 13.1 & 4.8 & 828 & & 69.2 & 27.2 & 169 & -35.8 & -72.9 & -0.37 \\
\hline & 4 & 19 & 530 & 452 & 41.9 & 13.6 & 11.7 & 4.8 & 789 & & 70.3 & 28.2 & 131 & -35.4 & -73.4 & -0.41 \\
\hline & 5 & 24 & 544 & 474 & 44.0 & 15.5 & 11.8 & 5.7 & 800 & & 81.4 & 26.8 & 129 & -35.3 & -72.9 & -0.31 \\
\hline
\end{tabular}



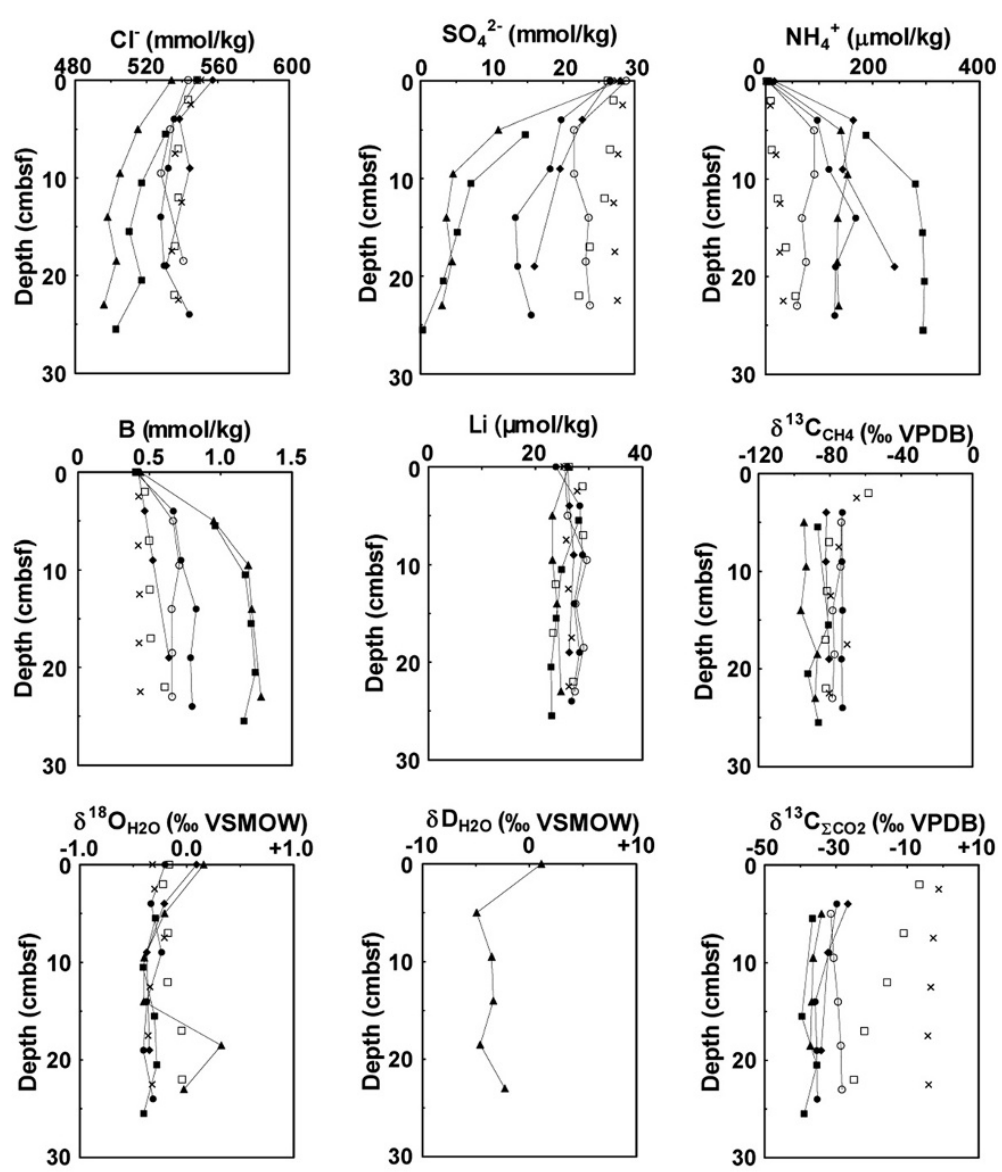

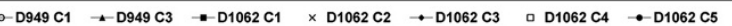

Figure 2 Vertical profiles of chemical and isotope components of pore water from sediments in Oomine Ridge. The points representing samples from cold seep sites are connected by lines to differentiate them from reference site data.

316 Scientists 2009a). Very few cold seep sites have been observed near the surface trace of the megasplay fault near Site C0004 (Ashi et al. 2009b). These observations suggest that the megasplay near Site C0004 is not an active pathway for reductive fluids. A possible explanation for the different character of the megasplay between Oomine and C0004 is the difference in tectonic and hydrologic activities along the strike of the megasplay fault (e.g., Kimura et al. 2011).
Isotopic compositions of pore fluids at cold seep sites on the Oomine Ridge

At the cold seep sites on the Oomine Ridge, the observed $\delta^{18} \mathrm{O}_{\mathrm{H} 2 \mathrm{O}}$ and $\delta \mathrm{D}_{\mathrm{H} 2 \mathrm{O}}$ were negative (Figure 2), which led Toki et al. (2004) to conclude that these fluids originated from groundwater. As suggested in 'Origin of B in of pore fluids at cold seep sites on the Oomine Ridge' section, however, if the fluids were derived from CMD, the values of $\delta^{18} \mathrm{O}_{\mathrm{H} 2 \mathrm{O}}$ and $\delta \mathrm{D}_{\mathrm{H} 2 \mathrm{O}}$ would be positive and negative,

Table 4 Chemical and isotopic compositions of end members for the estimation in this study

\begin{tabular}{|c|c|c|c|c|c|}
\hline Sources & $\mathrm{C1}^{-}$ & $\mathrm{B} \mathrm{mmol} / \mathrm{kg}$ & $\delta^{18} \mathrm{O}_{\mathrm{H} 2 \mathrm{O}} \%$ VSMOW & $\delta D_{\mathrm{H} 2 \mathrm{O}} \%$ VSMOW & Reference \\
\hline SW & $547 \pm 8$ & $0.4116 \pm 0.015$ & $-0.09 \pm 0.21$ & $+1.1 \pm 1.0$ & This study \\
\hline CMD & 0 & $23 \pm 8$ & ND & ND & Toki et al. 2013 \\
\hline SPF & $549 \pm 4$ & $0.217 \pm 0.057$ & $-2.5 \pm 0.4$ & $-10.0 \pm 2.8$ & Expedition 315 Scientists 2009a \\
\hline $\mathrm{MH}$ & 0 & 0 & $+0.6 \pm 0.4$ & $+8.0 \pm 2.8$ & Expedition 315 Scientists 2009a; Maekawa 2004 \\
\hline Oomine & 498 & 1.3 & -0.4 & -3.4 & This study \\
\hline
\end{tabular}




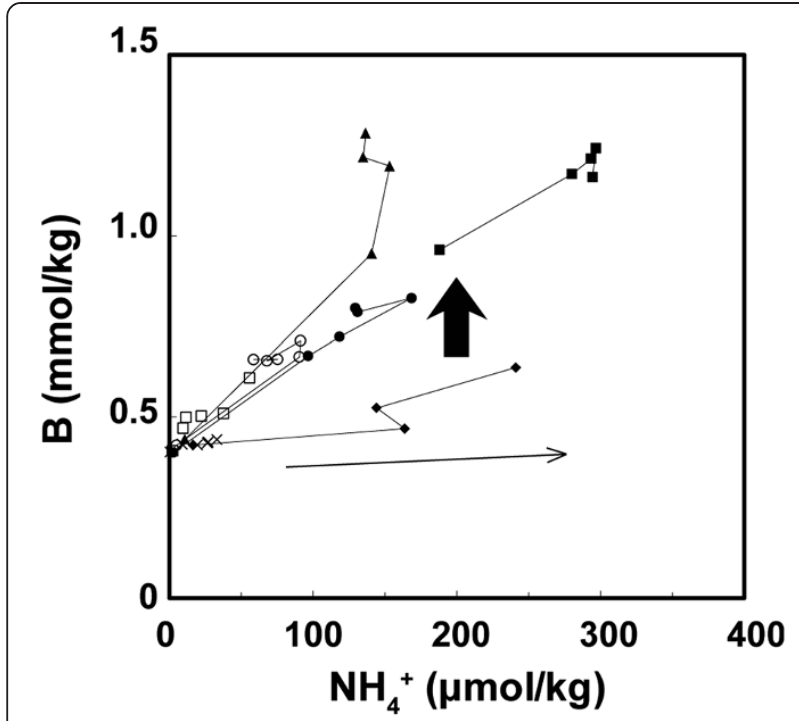

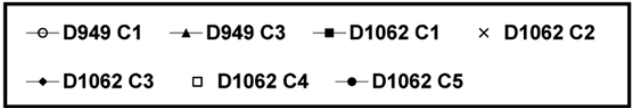

Figure 3 Relationship between $\mathrm{NH}_{4}^{+}$and $\mathrm{B}$ concentrations in pore water from the Oomine Ridge. The thin arrow represents $\Delta \mathrm{B} / \Delta \mathrm{NH}_{4}^{+}$ratios of approximately $0.1 \mathrm{~mol} / \mathrm{mol}$ for $\mathrm{B}$ derived from only organic matter desorption. The thick arrow indicates the manner in which B concentrations are enriched compared with those derived from only organic matter desorption. The sample numbers are given in Table 1.

respectively (Magaritz and Gat 1981). It is possible that during their ascent to the seafloor, fluids derived from CMD mixed with fluids in sediments shallower than the estimated depth range of 1.5 to $3.5 \mathrm{~km}$ bsf, where temperatures from $50^{\circ} \mathrm{C}$ to $160^{\circ} \mathrm{C}$ enable CMD to occur. Such chemical and isotopic features have been reported in the Barbados subduction zone, although the distribution of $\delta \mathrm{D}_{\mathrm{H} 2 \mathrm{O}}$ has not been explained by any possible processes in the sediments (Vrolijk et al. 1990, 1991).

The chemical and isotopic compositions of the Oomine Ridge cold seep pore fluids also reflect the mixing of low $\mathrm{Cl}^{-}, \delta^{18} \mathrm{O}$, and $\delta \mathrm{D}$ fluids with SW (Figure 2). The data for $\mathrm{Cl}^{-}$and $\delta^{18} \mathrm{O}$, however, are scattered (Figure 2), implying that the pore fluids did not result from the simple mixing of two sources such as SW and another end member. Among the cold seep samples, sample D949 C3-3 $\left(\mathrm{Cl}^{-}=498 \mathrm{mmol} / \mathrm{kg}, \quad \mathrm{B}=1.3 \mathrm{mmol} / \mathrm{kg}\right.$, $\delta^{18} \mathrm{O}_{\mathrm{H} 2 \mathrm{O}}=-0.4 \%$, $\delta \mathrm{D}_{\mathrm{H} 2 \mathrm{O}}=-3.4 \%$ ) differs most from $\mathrm{SW}$ with respect to these values (Figure 2). If the data of D949 C3-3 can be explained by some end members, the other data also can be explained by those end members with different mixing ratios. Therefore, we examined various possible sources in which the mixing with freshwater derived from CMD might explain the chemical and isotopic compositions of the pore fluids in the cold seeps on the Oomine Ridge.

\section{Possible sources of fluids in cold seeps on the Oomine Ridge \\ Seawater}

First, we calculated the chemical and isotopic compositions of the SW samples from D949 (C1-0 and C3-0) and D1062 (C2-0, C3-0, C4-0, and C5-0), which consisted of SW overlying the sediment in each corer collected just before the sediments were sampled (Table 3 ). The chemical and isotopic compositions in these samples were averaged as $\mathrm{Cl}^{-}=547 \pm 8 \mathrm{mmol} / \mathrm{kg}, \mathrm{B}=$ $0.416 \pm 0.015 \mathrm{mmol} / \mathrm{kg}, \delta^{18} \mathrm{O}_{\mathrm{H} 2 \mathrm{O}}=-0.09 \pm 0.21 \%$, and $\delta \mathrm{D}_{\mathrm{H} 2 \mathrm{O}}=+1.1 \pm 1.0 \%$. All of these values fall within the range of those of North Pacific deep SW (Reid 2009); therefore, we adopted these values for the chemical and isotopic compositions of SW in this study.

\section{Freshwater derived from CMD}

The chemical and isotopic compositions of freshwater derived from CMD $\left(\delta^{18} \mathrm{O}_{\mathrm{CMD}}\right.$ and $\left.\delta \mathrm{D}_{\mathrm{CMD}}\right)$ depend on those of the clay minerals $\left(\delta^{18} \mathrm{O}_{\text {clay }}\right.$ and $\left.\delta \mathrm{D}_{\text {clay }}\right)$ and the equilibrium temperature $T(\mathrm{~K})$ of the reaction. The isotopic fractionation between clay minerals and ambient pore fluids for $\delta^{18} \mathrm{O}$ (Sheppard and Gilg 1996) and $\delta \mathrm{D}$ (Capuano 1992) is expressed as a function of the reaction temperature:

$$
\begin{gathered}
\delta^{18} \mathrm{O}_{\text {clay }}-\delta^{18} \mathrm{O}_{\mathrm{CMD}}=\frac{2.55 \times 10^{6}}{T^{2}}-4.05 \\
\delta \mathrm{D}_{\text {clay }}-\delta \mathrm{D}_{\mathrm{CMD}}=-\frac{4.53 \times 10^{4}}{T}+94.7
\end{gathered}
$$

In these equations, we considered $\delta^{18} \mathrm{O}_{\text {clay }}$ to range from $+17 \%$ to $+26 \%$ and $\delta \mathrm{D}_{\text {clay }}$ to range from $-95 \%$ to $+33 \%$ because these are the reported value ranges for clay minerals in marine sediments (Savin and Epstein 1970; Yeh 1980; Capuano 1992). Then, using Equations 1 and 2, we calculated $\delta^{18} \mathrm{O}_{\mathrm{CMD}}$ to range between $-3 \%$ and $+17 \%$ and $\delta \mathrm{D}_{\mathrm{CMD}}$ to range between $-85 \%$ and $+79 \%$ for a temperature range of $50^{\circ} \mathrm{C}$ to $160^{\circ} \mathrm{C}$. The $\mathrm{B}$ concentration of freshwater derived from CMD is unknown; therefore, we used the value of the Kumano mud volcanoes near the study area $(23 \pm 8 \mathrm{mmol} / \mathrm{kg})$ as the reference value (Toki et al. 2013). Since the value of $23 \mathrm{mmol} / \mathrm{kg}$ is taken from the mud volcano site, the accuracy should be lower, and the error would be larger than $8 \mathrm{mmol} / \mathrm{kg}$. But this value is essential to the modeling, and it should be stated for the fairness.

Shallow pore fluids in Nankai accretionary prism sediment From 2007 to 2008, during IODP Expeditions 315 and 316, D/V Chikyu drilled into the slope of the Nankai 
accretionary prism to a depth of up to $1,052 \mathrm{~m}$ bsf and recovered pore fluids from the sediments (Figure 1b) (Ashi et al. 2009a; Screaton et al. 2009). Pore fluid $\delta^{18} \mathrm{O}_{\mathrm{H} 2 \mathrm{O}}$ and $\delta \mathrm{D}_{\mathrm{H} 2 \mathrm{O}}$ values at Sites $\mathrm{C} 0001$ and $\mathrm{C} 0002$, drilled during Expedition 315, have been reported (Expedition 315 Scientists 2009b), although at Sites C0004 and C0008, drilled during Expedition 316, only pore fluid $\delta^{18} \mathrm{O}_{\mathrm{H} 2 \mathrm{O}}$ has been reported (Expedition 316 Scientists $2009 \mathrm{a}, \mathrm{b})$. The $\delta^{18} \mathrm{O}_{\mathrm{H} 2 \mathrm{O}}$ and $\delta \mathrm{D}_{\mathrm{H} 2 \mathrm{O}}$ at all four sites, however, have been measured by Dr. $\mathrm{H}$. Tomaru using the method described by Expedition 315 Scientists (2009a). Dr. Tomaru distributed the data to all researchers associated with the drilling expeditions, including onshore researchers requesting the data. We therefore used these data to construct vertical profiles of $\delta^{18} \mathrm{O}_{\mathrm{H} 2 \mathrm{O}}$ and $\delta \mathrm{D}_{\mathrm{H} 2 \mathrm{O}}$ (Figure 4). At depths deeper than $200 \mathrm{~m}$ bsf at all sites drilled during Expeditions 315 and $316, \delta^{18} \mathrm{O}_{\mathrm{H} 2 \mathrm{O}}$ and $\delta \mathrm{D}_{\mathrm{H} 2 \mathrm{O}}$ were nearly constant: $\delta^{18} \mathrm{O}_{\mathrm{H} 2 \mathrm{O}}$ varied between $-4.5 \%$ and $-2 \%$, and $\delta \mathrm{D}_{\mathrm{H} 2 \mathrm{O}}$ varied between $-15 \%$ and $-10 \%$ (Figure 4 ). On the contrary, at depths shallower than $200 \mathrm{~m}$ bsf at all sites, these values gradually became close to that of SW. These gradients suggest that a fluid source with constant $\delta^{18} \mathrm{O}_{\mathrm{H} 2 \mathrm{O}}$ and $\delta \mathrm{D}_{\mathrm{H} 2 \mathrm{O}}$ below $200 \mathrm{~m}$ bsf would mix with SW above $200 \mathrm{~m}$ bsf. In such cases, the fluid source below $200 \mathrm{~m}$ bsf would be recognized as an end member in the shallow sediments of the Nankai accretionary prism slope (below $200 \mathrm{~m}$ bsf and above 1.5 to $3.5 \mathrm{~km} \mathrm{bsf}$ ). In this study, we refer to the fluids in the sediments of the Nankai accretionary prism slope below $200 \mathrm{~m}$ bsf and above 1.5 to $3.5 \mathrm{~km}$ bsf as shallow pore fluids (SPF). The SPF ubiquitous in the sediments of the Nankai accretionary prism slope would be mixed with deep-sourced fluids derived from CMD before seeping at the cold seep sites on the Oomine Ridge. In our subsequent discussion, we use the following chemical and isotopic compositions of SPF from Site C0001 on the outer ridge of the Nankai accretionary prism as SPF values: $\mathrm{Cl}^{-}=549 \pm 4 \mathrm{mmol} / \mathrm{kg}, \mathrm{B}=0.217 \pm 0.057 \mathrm{mmol} / \mathrm{kg}$, $\delta^{18} \mathrm{O}=-2.5 \pm 0.4 \%$, and $\delta \mathrm{D}=-10.0 \pm 2.8 \%$ o (Expedition 315 Scientists 2009a).

\section{Freshwater from methane hydrate dissociation}

A final factor that can influence the chemical and isotopic compositions of the pore fluids is the freshwater derived from $\mathrm{MH}$ dissociation. $\mathrm{MH}$ has never actually been recovered from Site C0001, which is situated in a position similar to the Oomine Ridge (Ashi et al. 2009a). However, discontinuous bottom-simulating reflectors (BSRs) suggesting the presence of $\mathrm{MH}$ have been observed beneath the slope of the Nankai accretionary prism (e.g., Colwell et al. 2004). Moreover, MH was recovered from several hundred meters below the seafloor at Site C0008, which is near the surface trace of another megasplay fault on the seaward side of the Oomine Ridge (Screaton et al. 2009). In general, $\mathrm{MH}$ is recovered where sand layers occur (Ginsburg et al. 2000), although beneath the Nankai accretionary prism slope, which is composed mainly of silty clay, dispersed $\mathrm{MH}$ may be present (Screaton et al. 2009). Taken together, these findings suggest that it is possible for freshwater derived from $\mathrm{MH}$ dissociation to contribute to the fluids supplied to the cold seeps on the Oomine Ridge. Therefore,

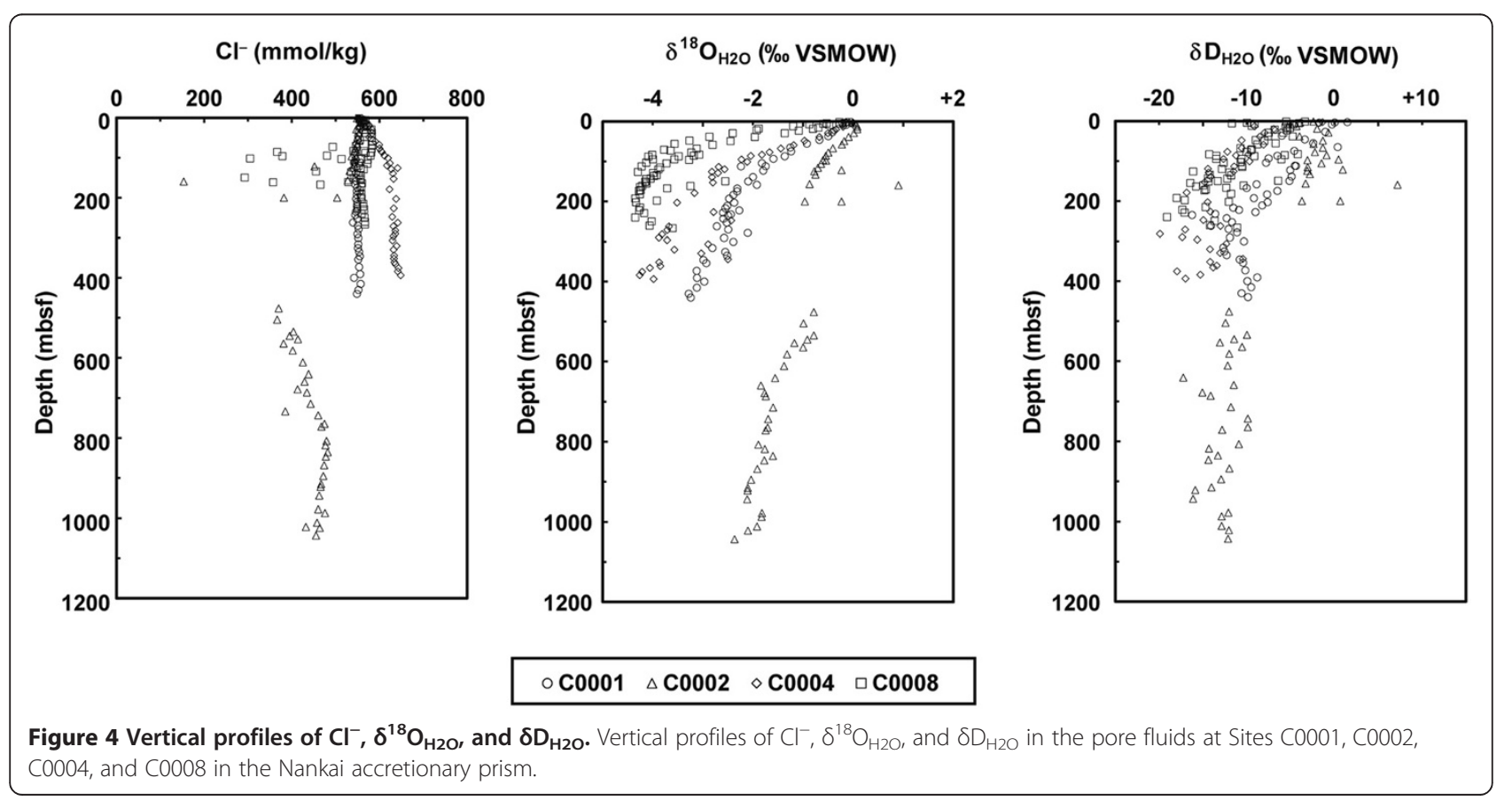


we also considered freshwater from $\mathrm{MH}$ dissociation in our estimation of possible contributions to the seepage fluid.

When $\mathrm{MH}$ forms in sediments, it consists mainly of $\mathrm{CH}_{4}$ and water, excluding salt from the ambient SW (e.g., Sloan and Koh 2008). When $\mathrm{MH}$ is recovered during drilling, the $\mathrm{MH}$ dissociates, depending on the temperature and pressure conditions, to release $\mathrm{CH}_{4}$ and water (Hesse and Harrison 1981; Ussler and Paull 1995). In vertical profiles of pore fluids, samples influenced by $\mathrm{MH}$ dissociation are characterized by a negative $\mathrm{Cl}^{-}$concentration spike and positive $\delta^{18} \mathrm{O}_{\mathrm{H} 2 \mathrm{O}}$ and $\delta \mathrm{D}_{\mathrm{H} 2 \mathrm{O}}$ values (Kvenvolden and Kastner 1990). Experimentally determined $\delta^{18} \mathrm{O}_{\mathrm{H} 2 \mathrm{O}}$ and $\delta \mathrm{D}_{\mathrm{H} 2 \mathrm{O}}$ fractionation factors during $\mathrm{MH}$ formation show a shift to heavier values from ambient water to the formation water; that is, $\Delta \delta^{18} \mathrm{O}$ shifts from $+2.8 \%$ o to $+3.2 \%$ o and $\Delta \delta \mathrm{D}$ shifts from $+16 \%$ o to $+20 \%$ o (Maekawa 2004; Maekawa and Imai 2000). Here, we adopt as the reference value $\Delta \delta^{18} \mathrm{O}=+3.1 \%$, which was obtained in the Nankai Trough gas hydrate area (Tomaru et al. 2004).

If $\mathrm{MH}$ has formed in the vicinity of the outer ridge, then, given the composition of the SPF at Site $\mathrm{C} 0001\left(\mathrm{Cl}^{-}=549 \pm\right.$ $4 \mathrm{mmol} / \mathrm{kg}, \delta^{18} \mathrm{O}_{\mathrm{H} 2 \mathrm{O}}=-2.5 \pm 0.4 \%$, and $\delta \mathrm{D}_{\mathrm{H} 2 \mathrm{O}}=-10.0 \pm$ $2.8 \%$ ) and the experimentally determined isotope fractionation values of $\Delta \delta^{18} \mathrm{O}=+3.1 \%$ and $\Delta \delta \mathrm{D}=+16 \%$ to $+20 \%$, the isotopic composition of the formation water of $\mathrm{MH}$ can be estimated to be $\delta^{18} \mathrm{O}_{\mathrm{H} 2 \mathrm{O}}=+0.6 \pm$ $0.4 \%$ and $\delta \mathrm{D}_{\mathrm{H} 2 \mathrm{O}}=+6.0 \pm 2.8 \%$ o to $+10.0 \pm 2.8 \%$. We used these values to calculate the contribution of $\mathrm{MH}$ dissociation to the pore fluids on the Oomine Ridge.

\section{Mixing model for the formation of fluids supplied to the Oomine Ridge cold seeps}

We used a mixing model to explain the compositions of pore fluid at the Oomine Ridge cold seeps. Using the end-member values listed in Table 4, we solved the following equations:

$$
\begin{aligned}
\mathrm{Cl}^{-} \text {Oomine }= & X \times \mathrm{Cl}^{-}{ }_{\mathrm{SW}}+Y \times \mathrm{Cl}^{-}{ }_{\mathrm{CMD}}+Z \\
& \times \mathrm{Cl}^{-}{ }_{\mathrm{SPF}}+W \times \mathrm{Cl}^{-}{ }_{\mathrm{MH}}, \\
\mathrm{B}_{\text {Oomine }}= & X \times \mathrm{B}_{\mathrm{SW}}+Y \times \mathrm{B}_{\mathrm{CMD}}+Z \times \mathrm{B}_{\mathrm{SPF}} \\
+ & W \times \mathrm{B}_{\mathrm{MH}}, \\
\delta^{18} \mathrm{O}_{\text {Oomine }}= & X \times \delta^{18} \mathrm{O}_{\mathrm{SW}}+Y \times \delta^{18} \mathrm{O}_{\mathrm{CMD}} \\
& +Z \times \delta^{18} \mathrm{O}_{\mathrm{SPF}}+W \times \delta^{18} \mathrm{O}_{\mathrm{MH}}, \\
\mathrm{DD}_{\text {Oomine }}= & X \times \delta \mathrm{D}_{\mathrm{SW}}+Y \times \delta \mathrm{D}_{\mathrm{CMD}}+Z \\
& \times \delta \mathrm{D}_{\mathrm{SPF}}+W \times \delta \mathrm{D}_{\mathrm{MH}} \\
X+Y+Z & +W=1
\end{aligned}
$$

where each source is denoted by a subscript previously defined. $X, Y, Z$, and $W$ denote the mixing ratios of $\mathrm{SW}$, $\mathrm{CMD}, \mathrm{SPF}$, and $\mathrm{MH}$ dissociation, respectively. The calculation outline is schematically drawn in Figure 5. Assuming the feasible combination of $\delta^{18} \mathrm{O}_{\mathrm{CMD}}$ and $\delta \mathrm{D}_{\mathrm{CMD}}$ given by Equations 1 and 2 for $50^{\circ} \mathrm{C}$ to $160^{\circ} \mathrm{C}$ as the reaction temperature of $\mathrm{CMD}$, we calculated the mixing ratios where the Oomine seep values lie on the same plane as that of the combination of SW, CMD, $\mathrm{SPF}$, and $\mathrm{MH}$ values. For obtained mixing ratios, we verified the existence of a solution in which the predicted $B$ concentration coincides with the observed B concentration; thus, we can accept the results. At first, we considered three-end-member mixing model. One of four mixing ratios $(X-W)$ is forced to zero, and all Equations 3, $4,5,6$, and 7 are used to statistically obtain the other three ratios. Although several attempts were made by normalizing the coefficients to the same magnitude, all four cases resulted in prediction error much larger than $10 \%$. Thus, neglecting any factor of the four ratios was rejected.

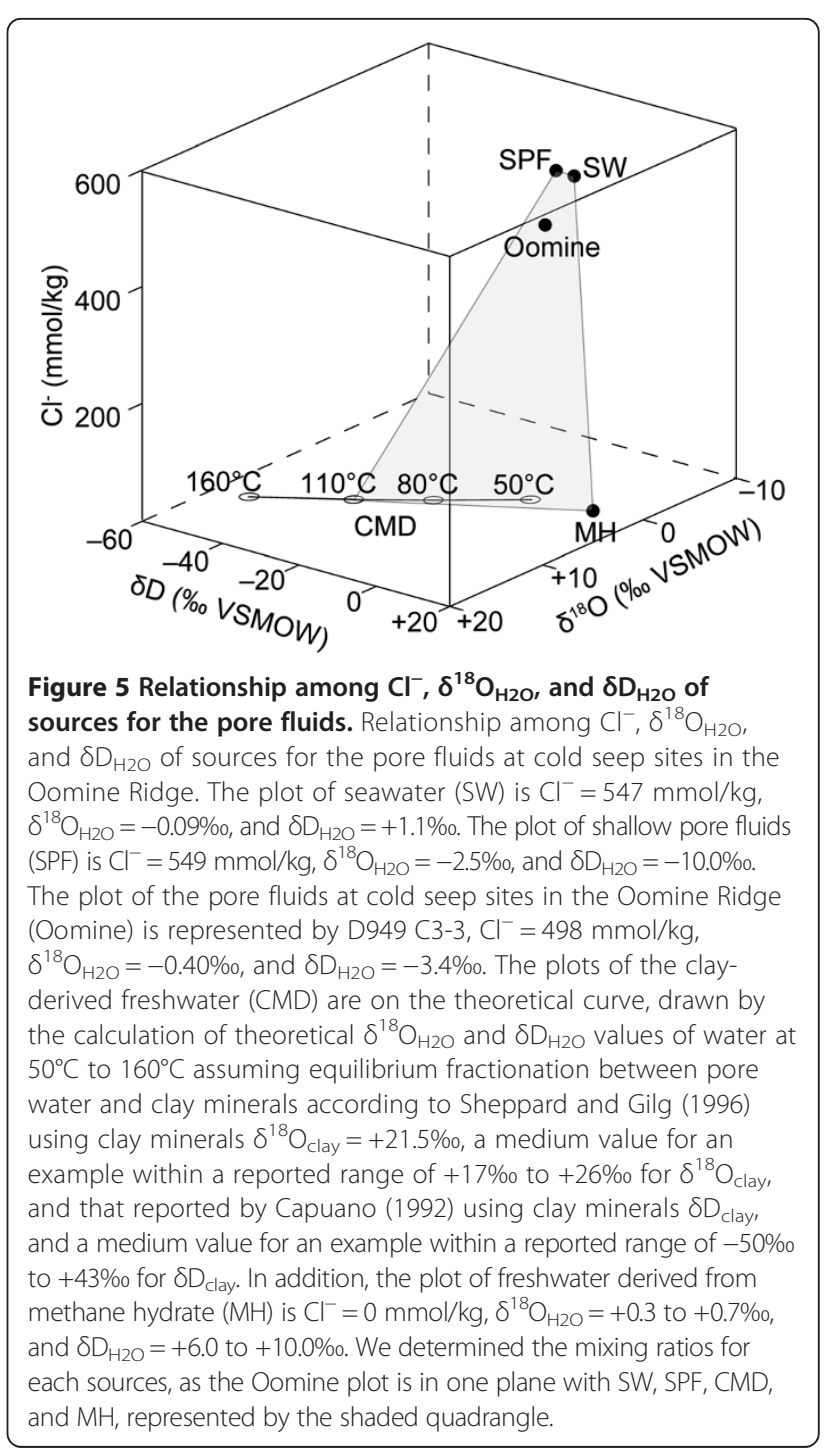


When we consider a mixing model with four components (end members) including SW, freshwater derived from CMD, SPF, and freshwater derived from $\mathrm{MH}$ dissociation, several solutions are possible. For example, for an equilibrium temperature of $160^{\circ} \mathrm{C}$, we obtained the solution $(X, Y, Z, W)=(0.47,0.044,0.44,0.047)$ and $\left(\delta^{18} \mathrm{O}_{\mathrm{CMD}}, \delta \mathrm{D}_{\mathrm{CMD}}\right)=(+16.5 \%$ o, $+3 \%$ ) ; for an equilibrium temperature of $110^{\circ} \mathrm{C}$, we obtained $(X, Y, Z, W)=(0.70$, $0.042,0.21,0.048)$ and $\left(\delta^{18} \mathrm{O}_{\mathrm{CMD}}, \delta \mathrm{D}_{\mathrm{CMD}}\right)=(+3.7 \%$, $-59 \%)$. Using other clay mineral compositions and equilibrium temperatures, other solutions are possible. In particular, for $\left(\delta^{18} \mathrm{O}_{\text {clay }}, \delta \mathrm{D}_{\text {clay }}\right)=(+26 \%$ o, $-95 \%$ o $)$ and for an equilibrium temperature of $50^{\circ} \mathrm{C}$, we obtained $(X, Y, Z, W)=$ $(0.67,0.042,0.24,0.048)$ and $\left(\delta^{18} \mathrm{O}_{\mathrm{CMD}}, \quad \delta \mathrm{D}_{\mathrm{CMD}}\right)=$ $(+5.6 \%$ o, $-50 \%)$. These results indicate that although it is not possible with this model to constrain the equilibrium temperature, the four-end-member model can nevertheless explain the seepage fluid compositions. We conclude that both MH dissociation and SPF contribute to the pore fluids in the cold seeps on the Oomine Ridge. The results indicate that the contributions of SW and SPF, SW > 40\% and $\mathrm{SPF}=20 \%$ to $50 \%$, are dominant, followed by freshwater from clay minerals, $\mathrm{CMD}=$ approximately $4 \%$, and $\mathrm{MH}$ dissociation, $\mathrm{MH}=$ approximately $5 \%$, which contributes the least. The most important finding is that pore fluids at cold seep sites on the Oomine Ridge cannot be explained without considering CMD, SPF, and $\mathrm{MH}$ dissociation.

\section{Behavior of pore fluids in sediments off Kumano}

At the seepage sites on the Oomine Ridge, the observed $B$ concentrations were greater than could be explained by organic matter degradation, suggesting that the seeps at the site are supplied with fluids derived from CMD at $50^{\circ} \mathrm{C}$ to $160^{\circ} \mathrm{C}$ Toki et al. (2013) have shown that $\mathrm{Li}$ as well as B is supplied to the Kumano mud volcanoes and that the presence of $\mathrm{Li}$ can be attributed to the fluids passing through layers with temperatures of $150^{\circ} \mathrm{C}$ to $160^{\circ} \mathrm{C}$ before reaching the seepage sites. The isotopic compositions of the pore fluids of the mud volcanoes also indicate derivation from CMD (Toki et al. 2013). Thus, the mud volcano fluids ascend from about $4 \mathrm{~km}$ bsf (Figure 6; Source A). Moreover, these deep-origin fluids are not overprinted by other fluids in the shallow sediments during their ascent. This scenario can explain the concentrations of other components derived from great depth, including B and Li. The sediment thickness in Kumano Basin is only about $2 \mathrm{~km}$ (Expedition 315 Scientists 2009b); therefore, the rock around Source A at $4 \mathrm{~km}$ bsf is likely composed of old accretionary sediments in the lower part of the accretionary prism (Figure 6).

The results obtained in this study suggest that the pore fluid composition at the seepage sites on the Oomine Ridge reflects contributions from other sources, in addition to freshwater from CMD. Therefore, as the source fluids ascend from depth below the seafloor, they likely mix with pore fluids in the shallower layers of the accretionary prism before finally seeping out at the seafloor. However, when we considered the contributions only from SPF in the shallow accretionary prism, which is represented by fluids obtained during deep drilling, freshwater derived from CMD, and SW, the resulting contribution ratios could not explain the observed $\mathrm{B}$ concentration ('Shallow pore fluids in Nankai accretionary prism sediment' section). When we also considered a contribution of fluids derived from $\mathrm{MH}$ dissociation, we obtained the following contribution ratios in the seepage fluid ('Freshwater derived from CMD' section): about 4\% fluid derived from CMD, about 5\% fluid derived from $\mathrm{MH}$ dissociation, $20 \%$ to $50 \%$ SPF of the accretionary prism, and more than 40\% SW (Figure 6; Source B).

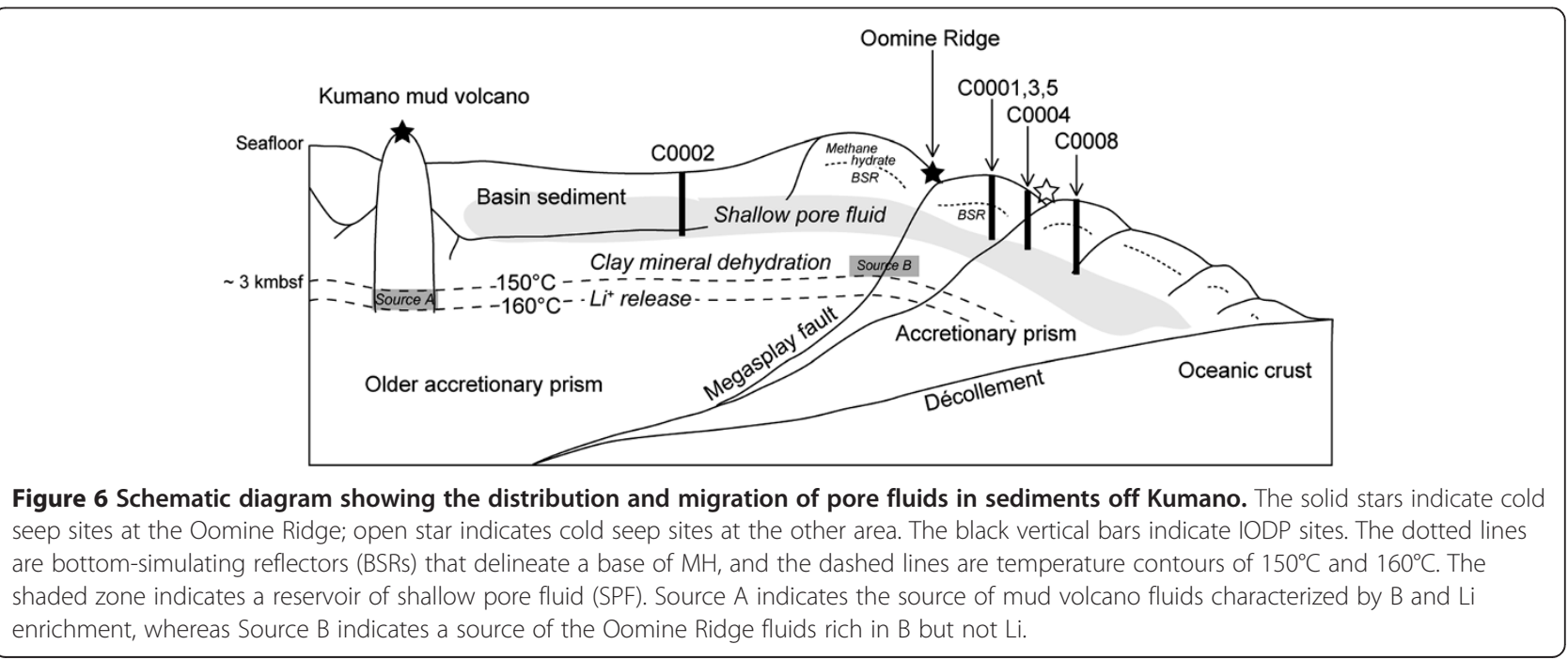


These ratios can explain the observed chemical and isotopic compositions of the pore fluids at the cold seep sites on the Oomine Ridge. Therefore, we conclude that fluids from $\mathrm{MH}$ dissociation, CMD, and SPF likely contribute to the pore fluids of the cold seeps.

The results of our estimation of fluid sources suggest that the mode of transport differs between the Oomine Ridge and the Kumano mud volcanoes. In the case of the Kumano mud volcanoes, both source fluids in sediments and the sediments themselves ascend to the seafloor, whereas on the Oomine Ridge, the source fluids mix with SPF sediments and with fluid from $\mathrm{MH}$ dissociation as they ascend to the seafloor, although the sediments themselves do not ascend. These different modes of fluid transport are consistent with hydrocarbon distribution differences between the Kumano mud volcanoes and the Oomine Ridge. Hydrocarbons of thermogenic origin are found only in the Kumano mud volcanoes, even though the fluids supplied to both the seepage sites on the Oomine Ridge and the Kumano mud volcanoes originate in environments with temperatures of more than $50^{\circ} \mathrm{C}$ (Toki et al. 2013). $\mathrm{CH}_{4}$ of microbial origin is distributed ubiquitously in the shallow sediments above several hundred meters below the seafloor in the accretionary prism off Kumano (Toki et al. 2012). Thus, sediments containing hydrocarbons of thermogenic origin rise to the seafloor within the Kumano mud volcanoes and are observed in the pore fluids in the subsurface sediments. In contrast, the fluids supplied to the Oomine Ridge contain $\mathrm{CH}_{4}$ of microbial origin from the shallow sediments through which the fluids passed during their ascent to the seafloor.

On the basis of the correlation between decreases in the isotopic compositions of the pore fluids and $\mathrm{Cl}^{-}$concentration, Toki et al. (2004) inferred that the source of the seepage fluids on the Oomine Ridge is laterally transported meteoric water. The drilling beneath the seafloor since 2007 has revealed chemical and isotopic compositions of the pore water in the sediments to several hundred meters below the seafloor. The isotopic compositions of the pore water in the shallow sediments of Nankai accretionary prism both had negative values, similar to those of meteoric water (Figure 2). In this study, we focused on B concentrations in the pore fluids, which showed that the seepage fluids on the Oomine Ridge as well as Kumano mud volcano fluids are influenced by freshwater derived from CMD. The source fluids of the cold seeps can thus become mixed with SPF during their ascent to the seafloor. We observed no $\mathrm{Li}$ anomaly on the Oomine Ridge; thus, the source fluids did not pass through environments with temperatures above $150^{\circ} \mathrm{C}$. We cannot rule out the possibility, however, that the characteristics of the original fluids in the deeper environments have been changed by mixing with SPF in the shallower sediments during the ascent. In the future, by conducting experiments with water and rock to determine trace elements not analyzed by You et al. (1996), a tracer that sensitively records information from deeper environments should be identified and utilized.

\section{Conclusions}

The results of this study are summarized in the following points:

(1)During cruises YK06-03 and YK08-04 of the tender Yokosuka, we collected pore water samples at cold seep sites on the Oomine Ridge. In these pore fluid samples, we found B derived from smectite-illite alteration, which suggests that the fluids were derived from environments with temperatures between $50^{\circ} \mathrm{C}$ and $160^{\circ} \mathrm{C}$.

(2) Our estimation of the source fluids based of a mixing model including a contribution of fluid from $\mathrm{MH}$ dissociation indicated that a mixture containing about 4\% freshwater derived from CMD, about 5\% freshwater derived from $\mathrm{MH}$ dissociation, $20 \%$ to $50 \%$ SPF from accretionary prism sediments, and more than $40 \%$ SW can explain the chemical and isotopic compositions of the cold seep fluids on the Oomine Ridge.

(3) The fluids seeping on the Oomine Ridge are transported from depth via faults and are mixed with SPF of the accretionary prism sediments and freshwater derived from $\mathrm{MH}$ dissociation prior to reaching the seafloor. This transport mode is clearly different from that of the fluids in mud volcanoes, which ascend together with sediments and do not mix with SPF.

\section{Competing interests}

The authors declare that they have no competing interests.

\section{Authors' contributions}

TT interpreted the data and wrote the manuscript. $\mathrm{RH}$ carried out chemical analyses, had a discussion and wrote the first draft. Al carried out the oxygen isotope measurements, had a discussion and modified the manuscript. UT thoroughly supported the isotopic analyses and modified the manuscript. JA organized the sampling campaign and modified the manuscript. All authors read and approved the final manuscript.

\section{Acknowledgements}

The authors thank the Shinkai6500 operation team and the captain and crew of the tender Yokosuka during cruises YK06-03 and YK08-04 for their continued dedication. We are grateful to Profs. S. Ohde, T. Oomori, and T. Matsumoto for their valuable comments that improved an earlier version of the manuscript. We also thank Prof. J. M. Gieskes and an anonymous reviewer for their constructive suggestions, as well as Dr. Masataka Kinoshita as the guest editor. We would like to express our sincere gratitude to Dr. Hitoshi Tomaru for providing the $\delta^{18} \mathrm{O}_{\mathrm{H}_{2} \mathrm{O}}$ and $\delta \mathrm{D}_{\mathrm{H}_{2} \mathrm{O}}$ data. This research was supported by a Grant-in-Aid for Scientific Research on Innovative Areas KANAME project. Moreover, during the writing of this paper, the authors were supported by the International Research Hub Project for Climate Change and Coral Reef/Island Dynamics from the University of the Ryukyus. 


\section{Author details}

'Department of Chemistry, Biology and Marine Science, Faculty of Science, University of the Ryukyus, 1 Senbaru, Nishihara, Okinawa 903-0213, Japan. ${ }^{2}$ Kochi Institute for Core Sample Research, JAMSTEC, B200 Monobe, Nankoku 783-8502, Japan. ${ }^{3}$ Earth and Planetary System Science, Faculty of Science, Hokkaido University, N10 W8, Kita-ku, Sapporo, Hokkaido 060-0810, Japan. ${ }^{4}$ Department of Ocean Floor Geoscience, Atmosphere and Ocean Research Institute, The University of Tokyo, 5-1-5 Kashiwanoha, Kashiwa, Chiba 277-8568, Japan. ${ }^{5}$ Current address: Graduate School of Environmental Studies, Nagoya University, Furo-cho, Chikusa-ku, Nagoya 464-8601, Japan.

\section{Received: 18 December 2013 Accepted: 30 September 2014}

\section{Published online: 24 October 2014}

\section{References}

Aharon P, Fu B (2000) Microbial sulfate reduction rates and sulfur and oxygen isotope fractionations at oil and gas seeps in deepwater Gulf of Mexico. Geochim Cosmochim Acta 64:233-246

Aloisi G, Drews M, Wallmann K, Bohrmann G (2004) Fluid expulsion from the Dvurechenskii mud volcano (Black Sea): Part I. Fluid sources and relevance to $\mathrm{Li}, \mathrm{B}, \mathrm{Sr}, \mathrm{I}$ and dissolved inorganic nitrogen cycles. Earth Planet Sci Lett 225:347-363

Ashi J, Lallemant S, Masago H, Expedition 315 Scientists (2009a) In: Kinoshita M, Tobin H, Ashi J, Kimura G, Lallemant S, Screaton EJ, Curewitz D, Masago H, Moe KT, Expedition 314/315/316 Scientists (ed) Proceedings of the Integrated Ocean Drilling Program, 314/315/316. Integrated Ocean Drilling Program Management International, Inc, Washington DC

Ashi J, Tsuji T, Ikeda Y, Morita S, Hashimoto Y, Sakaguchi A, Ujiie K, Saito S, Kuramoto S (2009b) Seafloor expressions of fault activities in the Nankai accretionary prism off Kumano. In: AGU Fall Meeting. San Francisco, 14 December 2009

Brumsack HJ, Zuleger E, Gohn E, Murray RW (1992) Stable and radiogenic isotopes in pore waters from leg 127, Japan Sea. Proceedings of the Ocean Drilling Program, Scientific Results, 127/128: Ocean Drilling Program. College Station, pp 635-650

Bufflap SE, Allen HE (1995) Sediment pore water collection methods for trace metal analysis: A review. Water Res 29:165-177

Capuano RM (1992) The temperature dependence of hydrogen isotope fractionation between clay minerals and water: Evidence from a geopressured system. Geochim Cosmochim Acta 56:2547-2554

Chao H, You C, Wang B, Chung C, Huang K (2011) Boron isotopic composition of mud volcano fluids: Implications for fluid migration in shallow subduction zones. Earth Planet Sci Lett 305:32-44

Colwell F, Matsumoto R, Reed D (2004) A review of the gas hydrates, geology, and biology of the Nankai Trough. Chem Geol 205:391-404

Dählmann A, de Lange GJ (2003) Fluid-sediment interactions at Eastern Mediterranean mud volcanoes: a stable isotope study from ODP Leg 160. Earth Planet Sci Lett 212:377-391

Deyhle A, Kopf A (2002) Strong B enrichment and anomalous $\delta^{11} B$ in pore fluids from the Japan Trench forearc. Mar Geol 183:1-15

Expedition 315 Scientists (2009a) Expedition 315 Site C0001. In: Kinoshita M, Tobin H, Ashi J, Kimura G, Lallemant S, Screaton EJ, Curewitz D, Masago H, Moe KT, Expedition 314/315/316 Scientists (ed) Proceedings of the Integrated Ocean Drilling Program, 314/315/316. Washington DC, pp 1-104

Expedition 315 Scientists (2009b) Expedition 315 Site C0002. In: Kinoshita M, Tobin H, Ashi J, Kimura G, Lallemant S, Screaton EJ, Curewitz D, Masago H, Moe KT, Expedition 314/315/316 Scientists (ed) Proceedings of the Integrated Ocean Drilling Program, 314/315/316. Washington DC, pp 1-75

Expedition 316 Scientists (2009a) Expedition 316 Site C0004. In: Kinoshita M, Tobin H, Ashi J, Kimura G, Lallemant S, Screaton EJ, Curewitz D, Masago H, Moe KT, Expedition 314/315/316 Scientists (ed) Proceedings of the Integrated Ocean Drilling Program, 314/315/316. Integrated Ocean Drilling Program Management International, Inc, Washington DC, pp 1-107

Expedition 316 Scientists (2009b) Expedition 316 Site C0008. In: Kinoshita M, Tobin H, Ashi J, Kimura G, Lallemant S, Screaton EJ, Curewitz D, Masago H, Moe KT, Expedition 314/315/316 Scientists (ed) Proceedings of the Integrated Ocean Drilling Program, 314/315/316. Washington DC, pp 1-107

Gieskes JM, Gamo T, Brumsack H (1991) Chemical methods for interstitial water analysis aboard JOIDES Resolution. Ocean Drilling Program Texas A\&M University Technical Note 15:1-60
Gieskes J, Mahn C, Day S, Martin JB, Greinert J, Rathburn T, McAdoo B (2005) A study of the chemistry of pore fluids and authigenic carbonates in methane seep environments: Kodiak Trench, Hydrate Ridge, Monterey Bay, and Eel River Basin. Chem Geol 220:329-345

Ginsburg G, Soloviev V, Matveeva T, Andreeva I (2000) Sediment grain-size control on gas hydrate presence, sites 994, 995, and 997. In: Paull CK, Matsumoto R, Wallace PJ, Dillon WP (ed) Proceedings of the Ocean Drilling Program, Scientific Results, 164: Ocean Drilling Program. College Station, pp 237-249

Greinert J, Bollwerk SM, Derkachev A, Bohrmann G, Suess E (2002) Massive barite deposits and carbonate mineralization in the Derugin Basin, Sea of Okhotsk: precipitation processes at cold seep sites. Earth Planet Sci Lett 203:165-180

Haese RR, Hensen C, de Lange GJ (2006) Pore water geochemistry of eastern Mediterranean mud volcanoes: Implications for fluid transport and fluid origin. Mar Geol 225:191-208

Harris RN, Schmidt-Schierhorn F, Spinelli G (2011) Heat flow along the NanTroSEIZE transect: Results from IODP Expeditions 315 and 316 offshore the Kii Peninsula, Japan. Geochem Geophys Geosyst 12:Q0AD16

Hensen C, Nuzzo M, Hornibrook E, Pinheiro LM, Bock B, Magalhães VH, Brückmann W (2007) Sources of mud volcano fluids in the Gulf of Cadiz indications for hydrothermal imprint. Geochim Cosmochim Acta 71:1232-1248

Hesse R, Harrison WE (1981) Gas hydrates (clathrates) causing pore-water freshening and oxygen isotope fractionation in deep-water sedimentary sections of terrigenous continental margins. Earth Planet Sci Lett 55:453-462

Hiruta A, Snyder GT, Tomaru H, Matsumoto R (2009) Geochemical constraints for the formation and dissociation of gas hydrate in an area of high methane flux, eastern margin of the Japan Sea. Earth Planet Sci Lett 279:326-339

ljiri A, Tsunogai U, Gamo T (2003) A simple method for oxygen-18 determination of milligram quantities of water using $\mathrm{NaHCO}_{3}$ reagent. Rapid Commun Mass Spectrom 17:1472-1478

Itai T, Kusakabe M (2004) Some practical aspects of an on-line chromium reduction method for $\mathrm{D} / \mathrm{H}$ analysis of natural waters using a conventional IRMS. Geochem J 38:435-440

Kastner M, Elderfield H, Martin JB (1991) Fluids in convergent margins: what do we know about their composition, origin, role in diagenesis and importance for oceanic chemical fluxes? Philosophical Transactions of the Royal Society of London Series A - Mathematical Physical and Engineering Sciences 335:243-259

Kimura G, Moore GF, Strasser M, Screaton E, Curewitz D, Streiff C, Tobin H (2011) Spatial and temporal evolution of the megasplay fault in the Nankai Trough. Geochem Geophys Geosyst 12:Q0A008

Kvenvolden KA, Kastner M (1990) Gas hydrates of the Peruvian outer continental margin. Proceedings of the Ocean Drilling Program, Scientific Results, 112: Ocean Drilling Program. College Station, pp 517-526

Lein AY, Pimenov NV, Savvichev AS, Pavlova GA, Vogt PR, Bogdanov YA, Sagalevich AM, Ivanov MV (2000) Methane as a source of organic matter and carbon dioxide of carbonates at a cold seep in the Norway Sea. Geochem Int 38:232-245

Maekawa T (2004) Experimental study on isotopic fractionation in water during gas hydrate formation. Geochem J 38:129-138

Maekawa T, Imai N (2000) Hydrogen and oxygen isotope fractionation in water during gas hydrate formation. In: Holder GD, Bishnoi PR (ed) Gas hydrates: challenges for the future, vol 912. Annals New York Academy Sciences, pp 452-459

Magaritz M, Gat JR (1981) Review of the natural abundance of hydrogen and oxygen isotopes. In: Gat JR, Gonfiantini R (ed) Stable isotope hydrology deuterium and oxygen-18 in the water cycle. International Atomic Energy Agency, Vienna, pp 85-102

Manheim FT (1968) Disposable syringe techniques for obtaining small quantities of pore water from unconsolidated sediments. J Sediment Petrol 38:666-668

Martin JB, Kastner M, Henry P, Le Pichon X, Lallement S (1996) Chemical and isotopic evidence for sources of fluids in a mud volcano field seaward of the Barbados accretionary wedge. J Geophys Res 101:20325-20345

Mazurenko LL, Soloviev VA, Gardner JM, Ivanov MK (2003) Gas hydrates in the Ginsburg and Yuma mud volcano sediments (Moroccan Margin): results of chemical and isotopic studies of pore water. Mar Geol 195:201-210

Miyajima T, Yamada Y, Handa YT, Yoshii K, Koitabashi T, Wada E (1995) Determining the stable-isotope ratio of total dissolved inorganic carbon in lake water by GC/C/RMS. Limnol Oceanogr 40:994-1000

Murray RW, Miller DJ, Kryc KA (2000) Analysis of major and trace elements in rocks, sediments, and interstitial waters by inductively coupled plasma-atomic emission spectrometry (ICP-AES). Ocean Drilling Program Texas A\&M University Technical Note 29:1-27 
Naehr TH, Stakes DS, Moore WS (2000) Mass wasting, ephemeral fluid flow, and barite deposition on the California continental margin. Geology 28:315-318

Park J-O, Kodaira S (2012) Seismic reflection and bathymetric evidences for the Nankai earthquake rupture across a stable segment-boundary. Earth Planets Space 64:299-303

Park J-O, Tsuru T, Kodaira S, Cummins PR, Kaneda Y (2002) Splay fault branching along the Nankai subduction zone. Science 297:1157-1160

Parsons B, Sclater JG (1977) An analysis of the variation of ocean floor bathymetry and heat flow with age. J Geophysical Rearch 82:6B0585

Paull CK, Hecker B, Commeau R, Freeman-Lynde RP, Neumann C, Corso WP, Golubic S, Hook JE, Sikes E, Curray J (1984) Biological communities at the Florida escarpment resemble hydrothermal vent taxa. Science 226:965-967

Reid $J \mathrm{~L}$ (2009) On the world-wide circulation of the deeper waters of the world ocean: Scripps Institution of Oceanography, UC San Diego

Reitz A, Haeckel M, Wallmann K, Hensen C, Heeschen K (2007) Origin of saltenriched pore fluids in the northern Gulf of Mexico. Earth Planet Sci Lett 259:266-282

Savin SM, Epstein S (1970) The oxygen and hydrogen isotope geochemistry of ocean sediments and shales. Geochim Cosmochim Acta 34:48-63

Screaton EJ, Kimura G, Curewitz D, Expedition 316 Scientists (2009) Expedition 316 summary. In: Kinoshita M, Tobin H, Ashi J, Kimura G, Lallemant S, Screaton EJ, Curewitz D, Masago H, Moe KT, Expedition 314/315/316 Scientists (ed) Proceedings of the Integrated Ocean Drilling Program Expeditions, 314/315/316. Integrated Ocean Drilling Program Management International, Inc, Washington DC

Sheppard SMF, Gilg HA (1996) Stable isotope geochemistry of clay minerals. Clay Miner 31:1-24

Sloan EDJ, Koh CA (2008) Clathrate hydrates of natural gases (third edition). CRC, Taylor \& Francis Group, Boca Raton

Suess E, Ritger SD, Moore JC, Jones ML, Kulm LD, Cochrane GR (1985) Biological communities at vent sites along the subduction zone off Oregon. Bulletin of the Biological Society of Washington 6:474-484

Teichert BMA, Torres ME, Bohrmann G, Eisenhauer A (2005) Fluid sources, fluid pathways and diagenetic reactions across an accretionary prism revealed by Sr and B geochemistry. Earth Planet Sci Lett 239:106-121

Toki T, Tsunogai U, Gamo T, Kuramoto S, Ashi J (2004) Detection of low-chloride fluids beneath a cold seep field on the Nankai accretionary wedge off Kumano, south of Japan. Earth Planet Sci Lett 228:37-47

Toki T, Maegawa K, Tsunogai U, Kawagucci S, Takahata N, Sano Y, Ashi J, Kinoshita M, Gamo T (2011) Gas chemistry of pore fluids from Oomine Ridge on the Nankai accretionary prism. In: Ogawa Y, Anma R, Dilek Y (ed) Accretionary prisms and convergent margin tectonics in the Northwest Pacific Basin, vol. 8. Springer, Heidelberg, pp 247-262

Toki T, Uehara Y, Kinjo K, ljiri A, Tsunogai U, Tomaru H, Ashi J (2012) Methane production and accumulation in the Nankai accretionary prism: Results from IODP Expeditions 315 and 316. Geochem J 46:89-106

Toki T, Higa R, Tanahara A, ljiri A, Tsunogai U, Ashi J (2013) Origin of pore water in Kumano mud volcanoes (in Japanese with English abstract). Chikyukagaku (Geochemistry) 47:221-236

Tomaru H, Matsumoto R, Lu H, Uchida T (2004) Geochemical process of gas hydrate formation in the Nankai Trough based on chloride and isotopic anomalies in interstitial water. Resour Geol 54:45-51

Tsunogai U, Wakita H (1995) Precursory chemical changes in ground water: Kobe earthquake, Japan. Science 269:61-63

Tsunogai U, Yoshida N, Gamo T (2002) Carbon isotopic evidence of methane oxidation through sulfate reduction in sediment beneath cold seep vents on the seafloor at Nankai Trough. Mar Geol 187:145-160

Ussler W, Paull CK (1995) Effects of ion exclusion and isotopic fractionation on pore water geochemistry during gas hydrate formation and decomposition. Geo-Mar Lett 15:37-44

Vrolijk P, Chambers SR, Gieskes JM, O'Neil JR (1990) Stable isotope ratios of interstitial fluids from the northern Barbados accretionary prism, ODP Leg 110. In: Moore JC, Mascle A, Taylor E, Underwood MB (ed) Proceedings of the Ocean Drilling Program, Scientific Results, 110: Ocean Drilling Program. College Station, pp 189-205

Vrolijk P, Fisher A, Gieskes J (1991) Geochemical and geothermal evidence for fluid migration in the Barbados accretionary prism (ODP leg 110). Geophys Res Lett 18:947-950

Wallmann K, Linke P, Suess E, Bohrmann G, Sahling H, Schlüter M, Dählmann A, Lammers S, Greinert J, Von Mirbach N (1997) Quantifying fluid flow, solute mixing, and biogeochemical turnover at cold vents of the eastern Aleutian subduction zone. Geochim Cosmochim Acta 61:5209-5219

Yeh HW (1980) D/H ratios and late-stage dehydration of shales during burial. Geochim Cosmochim Acta 44:341-352

You CF, Gieskes JM (2001) Hydrothermal alteration of hemi-pelagic sediments: experimental evaluation of geochemical processes in shallow subduction zones. Appl Geochem 16:1055-1066

You C-F, Gieskes JM, Chen RF, Spivack AJ, Gamo T (1993a) lodide, bromide, manganese, boron, and dissolved organic carbon in interstitial waters of organic carbon-rich marine sediments: observations in the Nankai accretionary prism. In: Hill IA, Taira A, Firth JV (ed) Proceedings of the Ocean Drilling Program, Scientific Results, 131: Ocean Drilling Program. College Station, pp 165-174

You CF, Spivack AJ, Smith JH, Gieskes JM (1993b) Mobilization of boron in convergent margins: Implications for the boron geochemical cycle. Geology $21: 207-210$

You CF, Castillo PR, Gieskes JM, Chan LH, Spivack AJ (1996) Trace element behavior in hydrothermal experiments: Implications for fluid processes at shallow depths in subduction zones. Earth Planet Sci Lett 140:41-52

doi:10.1186/s40623-014-0137-3

Cite this article as: Toki et al:: Origin and transport of pore fluids in the Nankai accretionary prism inferred from chemical and isotopic compositions of pore water at cold seep sites off Kumano. Earth, Planets and Space 2014 66:137.

\section{Submit your manuscript to a SpringerOpen ${ }^{\circ}$ journal and benefit from:}

- Convenient online submission

- Rigorous peer review

- Immediate publication on acceptance

- Open access: articles freely available online

- High visibility within the field

- Retaining the copyright to your article

Submit your next manuscript at $>$ springeropen.com 